\title{
MIR191 Pre-miRNA
}

National Cancer Institute

\section{Source}

National Cancer Institute. MIR191 Pre-miRNA. NCI Thesaurus. Code C105990.

MIR191 pre-miRNA (92 bases) is encoded by the human MIR191 gene. This

ribonucleotide may be involved in the regulation of gene transcription. 